\title{
OXIDATIVE STRESS AND CYTOKINES' INVOLVEMENT IN THE OCCURENCE AND PROGRESSION OF DIABETIC COMPLICATIONS IN THE COVID-19 PANDEMIC CONTEXT
}

\author{
MARIANA CORNELIA TILINCA ${ }^{1,5}$, IULIAN MERLAN ${ }^{6 *}$, ANDREEA SALCUDEAN ${ }^{4,5}$, IOAN \\ TILEA $^{2,5}$, ENIKO NEMES-NAGY ${ }^{3}$ \\ IDepartment of Internal Medicine I, "George Emil Palade” University of Medicine, Pharmacy, Science and Technology of \\ Târgu Mureș, 540142, Romania \\ ${ }^{2}$ Department of Internal Medicine VIII, “George Emil Palade” University of Medicine, Pharmacy, Science and Technology \\ of Târgu Mureș, 540142, Romania \\ ${ }^{3}$ Department of Chemistry and Medical Biochemistry, "George Emil Palade" University of Medicine, Pharmacy, Science \\ and Technology of Târgu Mureș, 540142, Romania \\ ${ }^{4}$ Department of Ethics and Social Sciences, "George Emil Palade” University of Medicine, Pharmacy, Science and \\ Technology of Târgu Mureș, 540142, Romania \\ ${ }^{5}$ Emergency County Clinical Hospital, Târgu Mureș, 540042, Romania \\ ${ }^{6}$ County Clinical Hospital of Târgu Mureș, 540072, Romania
}

*corresponding author: iulian.merlan@gmail.com

Manuscript received: January 2021

\begin{abstract}
Diabetes mellitus is a metabolic disease presenting growing prevalence worldwide. Oxidative stress is involved in the development of micro- and macrovascular complications in diabetic patients. Several pro-oxidative pathways contribute to the production of reactive oxygen species which can damage different biomolecules and a variety of inflammatory cytokines are also involved in the aggravation of diabetic manifestations. COVID-19 infection enhances oxygen free radical production and intensifies the inflammation, thus has a negative impact on the evolution of diabetes mellitus and its complications. The complications of diabetes including the macrovascular and microvascular conditions as well as the psychological illnesses have a major influence on the patients' quality of life.
\end{abstract}

\section{Rezumat}

Diabetul zaharat este o boală metabolică prezentând o prevalență crescândă la nivel mondial. Stresul oxidativ este implicat în dezvoltarea complicațiilor de tip micro- și macrovascular la pacienții diabetici. Diverse procese pro-oxidative contribuie la producerea de specii reactive ale oxigenului care pot afecta diferite biomolecule și o varietate de citokine inflamatorii sunt implicate în agravarea manifestărilor diabetice. Infecția cu COVID-19 promovează producerea de radicali liberi ai oxigenului și intensifică inflamația, având astfel un impact negativ asupra evoluției diabetului zaharat și a complicațiilor sale, fiind implicat în decesul multor pacienți cu boli cronice. Complicațiile diabetului, atât cele macrovasculare şi microvasculare, cât și afecțiunile psihologice au o influență majoră asupra calităţii vieții pacientului.

Keywords: oxidative stress, cytokines, diabetes mellitus, COVID-19

\section{Introduction}

Diabetes mellitus (DM) is a complex, heterogeneous, chronic disease characterized by the presence of hyperglycaemia due to a deficiency of insulin secretion and/or decreased glucose consumption in the periphery with simultaneous impact on glucose, lipid and protein metabolism. Chronic hyperglycaemia causes vascular damage and leads to the occurrence of macrovascular (atherosclerotic, coronary, cerebrovascular and peripheral artery disease) and microvascular complications (diabetic retinopathy, neuropathy, and nephropathy). In 2017, The International Diabetes Federation reported that 415 million adults ( 1 in 11) had diabetes mellitus in
2015, the number of cases being predicted to rise to 642 million by 2040 [52].

For a better control of diabetes, it is recommended to assess the risk factors: obesity, smoking, lipid parameters, blood pressure, renal function. Many organ damage and comorbidities such as coronary heart disease, heart failure, cerebrovascular disease and kidney impairment have a greater prevalence in type 2 DM [49]. Diabetes mellitus, as a metabolic disorder, can lead to oxidative stress through production of reactive molecules. These are reactive oxygen species (ROS) and reactive nitrogen species (RNS), which initiate oxidative damage of biomolecules (proteins, lipids, nucleic acids), thus enhancing the development of several diseases. The penetration of reactive molecules 
through biological tissues can be different, but their presence is significant as they are formed in different cell structures such as cell membranes, cytoplasm, and in different cell organelles, including lysosomes, peroxisomes, mitochondria, nucleus and endoplasmic reticulum [18].

\section{Diabetes mellitus and SARS-CoV-2 infection}

Since the late 2019 severe acute respiratory syndrome coronavirus 2 (SARS-CoV-2) has rapidly spread throughout the world prompting World Health Organization to declare COVID-19 a global pandemic. Until the time of the writing of this review almost 192 million cases and more than 4.1 million deaths have been reported [79]. Despite previous reports of greater risk of diabetic patients for severe acute respiratory syndromes [8], this pattern has not been reported for COVID-19, although it was found that the prevalence of diabetes mellitus is significantly higher in patients with severe COVID-19 [21]. Diabetes mellitus and its complications and comorbidities (such as hypertension and heart disease) had a major influence on mortality and admission to hospital of the patients infected with SARS-CoV-2 [6] and this trend has been observed globally in many retrospective studies [9, $16,26,28,55,66]$. In one study higher blood glucose levels were observed in diabetic patients who did not survive COVID-19 during hospitalization than in those who recovered from this infection [67]. It was hypothesized that SARS-CoV-2 itself, like other viruses, may be responsible for oxidative stress (OS) $[37,50]$ which might further increase the existing imbalance already found in poorly controlled diabetes mellitus, opening the possibility for effective antioxidant treatment.

\section{Oxidative stress and cytokines in diabetes and its complications}

Nowadays, the mechanisms that generate oxidative stress in diabetic patients, and the role of the reactive oxygen species involved in the infection with SARS$\mathrm{CoV}-2$ represent an open subject for all specialists in this field.

Free radicals are molecules that contain an unpaired electron in an atomic orbital which makes them highly reactive and unstable. There are several types of reactive species, but the most important in this case are reactive oxygen species. The main source of ROS is the mitochondria while other sources are circumstantial and cumulative: inflammation, phagocytosis, ischemia/reperfusion, exercise, xanthine oxidase catalysed reactions, peroxisomes, arachidonate pathways $[43,68,82]$. Antioxidants are molecules capable of donating an electron to a free radical in order to neutralize it and prevent further cellular damage. Antioxidants are either produced during metabolic processes (glutathione) or are found in diet (vitamin
C). Oftentimes there is an imbalance between ROS and available antioxidants, resulting in damage of biomolecules such as nucleic acids, proteins, lipids. The term used to describe this imbalance is called oxidative stress [44, 68, 84].

Most ROS are produced in the cell by the mitochondrial electron transport chain (mETC) not only as byproducts of the normal metabolism, but they are also considered essential molecules in physiological processes of the cell $[13,59,63]$. Most of the superoxide is generated at Complex I and Complex III, but is also mediated by monoamine oxidase and electron transfer flavoprotein oxidoreductase. These processes are amplified by hypoxia and substrate availability $[20,84]$. There are many non-mitochondrial sources of ROS of which nicotinamide adenine nucleotide phosphate oxidase (NOS) and endothelial NOS (eNOS) are the most important in the course of diabetes mellitus and its vascular complications [70, 84].

The OS signalling pathway involves the redox (reduction/oxidation) mechanism through which ROS induce reversible and irreversible modifications of amino acids. Oxidation of cysteine during the redox process results in changes of the structure and function of the protein. Some of the modifications are reversible by reducing compounds [58].

Oxidative stress itself may impair insulin sensitivity and cause beta-cell dysfunction and eventually diabetes mellitus through several mechanisms involving inflammation, mitochondrial dysfunction, damaging of signalling pathways and apoptosis [38, 81, 82]. There are several molecular mechanisms of glucoseinduced damage in the development of all chronic diabetic complications: increased activity of glucose oxidation pathway (glycolysis), increased production of advanced glycation end-products (AGE), diacylglycerol formation and protein kinase $\mathrm{C}$ (PKC) activation, hyperactivity of the hexosamine pathway, increased flux through polyol pathway. In the hyperglycaemic state, there is an excess of superoxide anion radical produced mainly by mitochondria that induces oxidative stress which inflicts damage to nuclear DNA. The DNA repair mechanisms inhibit glyceraldehyde-3phosphate (GAP) dehydrogenase, resulting in high levels of GAP and other glycolytic intermediates. Within the cell, these molecules stimulate the pro-oxidative pathways $[31,73]$.

The intertwining of oxidative stress pathways with inflammatory pathways leads to pathophysiological outcomes at multiple levels. Dysfunction of the nuclear (erythroid-1) related factor pathway in diabetic cells reduces the production of antioxidant cytoprotective enzymes, such as superoxide dismutase and glutathiones-transferase [64]. As superoxide generation under hyperglycaemic conditions inflicts DNA damage and finally necrosis, the resulting cellular debris promotes a local inflammatory response. Inflammation may also be initiated or augmented by the activation of 


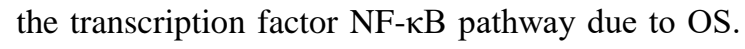
Oxidant species have a direct influence on the phosphorylation of inhibitory kappa B protein and subsequent release of free NF- $\kappa$ B heterodimer capable of crossing the nuclear membrane. Binding of NF- $\kappa B$ to genome promotes the production of inflammatory cytokines like tumour necrosis factor $\alpha$ (TNF- $\alpha$ ), interleukin-6, and cyclooxygenase-2 [64, 75, 76].

The activation of hexosamine pathway in the hyperglycaemic state leads to a cascade of reactions involving production of glucose-6-phosphate (G-6-P) from both glucose and glucosamine, which further represents the substrate for the generation of hexosamine products like proteoglycans, glycolipids and glycoproteins. On the other hand, glucosamine produced on this pathway contributes to the levels of $\mathrm{H} 2 \mathrm{O} 2$ to additionally increase oxidation. The toxic effects of ROS are mediated in this case by inhibition of glyceraldehydes3-phosphate dehydrogenase activity. This inhibition not only promotes an influx of hexosamine products, but also augments AGE pathway activity through the effect of methylglyoxal [80].

Microvascular disease refers to damage of the capillaries and arterioles at the level of the basement membrane that can lead to diabetic nephropathy, retinopathy, and cardiomegaly. The macrovascular disease represents atherosclerosis of the large vessels related to diabetes mellitus and involves myocardial infarction, stroke and foot gangrene. Oxidative stress, infections, and mechanical injuries contribute to endothelial dysfunction, an early trigger of atherosclerosis [47].

Several of the most frequently reported elements reported in SARS-CoV-2 infection are disseminated intravascular coagulopathy and hypoxia despite preserved pulmonary function [35], narrowing the cause at the mitochondrial level [4, 46, 72].

Individuals diagnosed with diabetes mellitus have a higher risk of subsequently developing macrovascular complications including myocardial infarction, stroke and peripheral artery disease. In myocardial injury secondary to ischemia and reperfusion, reactive species of oxygen play an integral role in diabetes mellitus. Following a myocardial infarction, OS led to an accumulation of calcium in mitochondria, up-regulating the formation of mitochondrial permeability transition pores with a direct effect on the membrane potential. These events have been linked with reperfusion injury $[7,30,74]$. The hydroxyl radical is produced both in the ischemia and reperfusion phases. Re-oxygenation of the cells combined with the previous accumulation of ROS during ischemia initiates a chain reaction in which more ROS are generated, the mitochondrial membrane potential is altered affecting the energy stores and pro-apoptotic signals are initiated [5, 41]. Transforming growth factor beta-1 (TGF- $\beta 1$ ) production and signalling in OS conditions induce the expression of BLC2-associated X protein which releases cytochrome-C, also resulting in apoptosis [62]. On the other hand, excessive TGF- $\beta 1$ signalling increases mitochondrial production of ROS, contributing to the overall OS and apoptosis.

Respiratory viral infections are known to induce OS by activation of NF- $\kappa \mathrm{B}$ pathway and deregulation of the nuclear transcription factor NF-E2-related factor 2 [36].

Some recent studies $[15,25,54]$ reported the so called "cytokine storm" as the most dangerous and lifethreatening event in COVID-19, while other authors consider this event just the manifestation of endothelial dysfunction and systemic inflammation [69]. Regardless of a lack of consensus, it is well documented that the inflammatory mediators such as interleukin-6 and Creactive protein found elevated in COVID-19 patients [14] contribute to the cyclic generation of OS in patients with diabetes mellitus [51].

In a septic medium rich in reactive oxygen species several alterations of erythrocyte membranes take place, ultimately generating heme and free iron which further induces damage to cells, apoptosis and blood coagulation [10]. It has been hypothesized that in patients with COVID-19 neutrophilia leads to OS that exacerbates the immune responses, in a process called reverse trans-endothelial migration of rigid, deregulated neutrophils which results in a more severe disease [39].

The combination of ROS and cytokines generate severe OS and organ failure in patients infected with SARSCoV-2 [10, 34]. It was found that in hospitalized diabetic patients with COVID-19 elevated serum glucose levels promoted cytokine profiles [86], but the use of glucose lowering agents such as metformin, which has the ability to inhibit proinflammatory cytokines [27], led to a more favourable prognosis. Consequently, both data from the medical literature as well as medical practice emphasize that an accumulation of ROS from both a poorly controlled diabetes mellitus and concomitant SARS-CoV-2 infection might generate a significant OS which could be an important factor in the prognosis and mortality of these category of patients [33]. Type 2 diabetes is a complex metabolic disease characterized not only by chronic hyperglycaemia, but also by an inflammatory state given the fact that obesity is frequently encountered in this condition [42]. Taken this into consideration various inflammatory biomarkers like CRP, MCP-1, TNF- alpha, IL-1 beta may be determined before and after starting the diabetic therapy in order to have an optimal management of the disease. There has been observed a positive association between circulating IL 10 levels and pro-inflammatory mediators such as CRP and IL 6 [57, 78].

\section{Antidiabetic medications with a potential anti- oxidant role}

Some blood glucose-lowering drugs are involved in the OS. Thus, metformin is the primary antidiabetic 
treatment used in type 2 diabetes mellitus for its benefits on weight loss, improvement of HbA1C levels and lipid profile with minimal risk of hypoglycaemia. Metformin therapy reduces ROS formation and consequently mitigates the damaging effects of OS. Administration of this biguanide has the potential of reducing the advanced oxidation protein products, AGE and pentosidine production while improving the activity of NOS through augmented blood flow $[1,12]$. Because of its structure, metformin may be able to interact with hydroxyl free radicals and $\alpha$-dicarbonyls. By reducing NADPH and oxidative reactions in mitochondria, metformin is limiting the production of ROS intracellularly. Another protective role is to reduce the concentration of insulin, thus diminishing the hyperinsulinism associated stress [19, 53]. In patients with poor glycaemic control and diabetic complications, with documented high OS levels, metformin could prevent further development of complications $[17,60,83]$.

Liraglutide is a glucagon like peptide-1 receptor agonist that improves glucose-dependent insulin secretion capacity and beta-cell function [77]. Beta-cells are sensitive to OS because of the diminished availability of local antioxidants. The incretin protects them by combating the oxidative species. Although the mechanisms by which liraglutide reduces OS is not fully understood, it is suggested that they involve cyclic AMP/protein kinase-A signalling pathway, phosphoinositide 3-kinase, and MAPK [11, 71, 85]. In experimental studies, vildagliptin reduced both oxidative stress and endoplasmic reticulum stress, thus preventing beta-cell apoptosis [2]. It directly increased beta-cell mass by promoting their differentiation and proliferation [22]. In clinical studies, vildagliptin was able to control acute glucose fluctuations, leading to a reduction of OS markers such as nitrotyrosine [61].

\section{Diabetes and mental health}

According to the literature individuals with diabetes mellitus have higher anxiety, depressive symptoms, panic attacks and impaired functioning especially when another stressor is added [45]. Clinical features such as sweating, anxiety, tachycardia and confusion are similar in both hypoglycaemic episodes and anxiety induced by a stressful life event. As up to $45 \%$ of the cases of mental health issues and diabetes-related psychological distress in individuals with diabetes goes undetected, the management of their mental and physical health amidst of COVID-19 pandemic outbreak is even more needed [23, 24, 40, 56].

It is well established that depression and type 2 diabetes are comorbid conditions with a bidirectional relationship [32]. There is a close association between type 2 diabetes and psychiatric diseases such as depression, anxiety disorders and alcohol dependence [29, 65].
The association between diabetes and mental health disorders could be exacerbated in a stressful environment and psychological distress could increase depressive symptoms and cause adverse diabetes outcomes. The emergence of a potentially fatal pandemic represents a new reason for uncertainty and anxiety in the group of diabetic patients $[3,48]$.

\section{Conclusions}

The assessment and follow-up of the circulating inflammatory biomarkers have a great importance in the management and also in the progression of diabetes mellitus.

Therefore, an attentive management is needed in type 2 diabetes which may include the measurement of inflammatory cytokines. This can improve the tracking of disease's evolution as well as medication effectiveness in order to delay the occurrence or progression of this condition. COVID-19 infection has a negative impact on the evolution of diabetes and its complications. There is a wide range of complications of diabetes including not only the macrovascular and microvascular conditions but also the psychological illnesses with a highly negative impact of the quality of life.

\section{Acknowledgement}

This work was supported by the University of Medicine, Pharmacy, Science and Technology "George Emil Palade" of Târgu Mureș, Romania, Research Grant number nr.294/6/14.01.2020.

\section{Conflict of interest}

The authors declare no conflict of interest.

\section{References}

1. Adeshara KA, Bangar NS, Doshi PR, Diwan A, Tupe RS, Action of metformin therapy against advanced glycation, oxidative stress and inflammation in type 2 diabetes patients: 3 months follow-up study. Diabetes Metab Syndr., 2020; 14(5): 1449-1458.

2. Aghahoseini F, Alihemmati A, Hosseini L, Badalzadeh $\mathrm{R}$, Vildagliptin ameliorates renal injury in type 2 diabetic rats by suppressing oxidative stress. $J$ Diabetes Metab Disord., 2020; 19(2): 701-707.

3. Alessi J, de Oliveira GB, Franco DW, Brino do Amaral B, Becker AS, Knijnik CP, Kobe GL, de Carvalho TR, Telo GH, Schaan BD, Telo GH, Mental health in the era of COVID-19: prevalence of psychiatric disorders in a cohort of patients with type 1 and type 2 diabetes during the social distancing. Diabetol Metab Syndr., 2020; 12(1): 76: 1-10.

4. Altay O, Arif M, Li X, Yang H, Aydın M, Alkurt G, Kim W, Akyol D, Zhang C, Dinler-Doganay G, Turkez H, Shoaie S, Nielsen J, Borén J, Olmuscelik O, Doganay L, Uhlén M, Mardinoglu A, Combined Metabolic Activators Accelerates Recovery in Mild- 
FARMACIA, 2021, Vol. 69, 4

to-Moderate COVID-19. Adv Sci., 2021; 2101222: 1-16.

5. Ansley DM, Wang B, Oxidative stress and myocardial injury in the diabetic heart. J Pathol., 2013; 229(2): 232-241.

6. Apicella M, Campopiano MC, Mantuano M, Mazoni L, Coppelli A, Del Prato S, COVID-19 in people with diabetes: understanding the reasons for worse outcomes. Lancet Diabetes Endocrinol., 2020; 8(9): 782-792.

7. Bagheri F, Khori V, Alizadeh AM, Khalighfard S, Khodayari S, Khodayari H, Reactive oxygen speciesmediated cardiac-reperfusion injury: Mechanisms and therapies. Life Sci., 2016; 165: 43-55.

8. Booth CM, Matukas LM, Tomlinson GA, Rachlis AR, Rose DB, Dwosh HA, Walmsley SL, Mazzulli T, Avendano M, Derkach P, Ephtimios IE, Kitai I, Mederski BD, Shadowitz SB, Gold WL, Hawryluck LA, Rea E, Chenkin JS, Cescon DW, Poutanen SM, Detsky AS, Clinical features and short-term outcomes of 144 patients with SARS in the greater Toronto area. JAMA, 2003; 289(21): 2801-2809.

9. Boye KS, Tokar Erdemir E, Zimmerman N, Reddy A, Benneyworth BD, Dabora MC, Hankosky ER, Bethel MA, Clark C, Lensing CJ, Sailer S, San Juan R, Heine RJ, Etemad L, Risk Factors Associated with COVID-19 Hospitalization and Mortality: A Large Claims-Based Analysis Among People with Type 2 Diabetes Mellitus in the United States. Diabetes Ther., 2021; 12(8): 2223-2239.

10. Cecchini R, Cecchini AL, SARS-CoV-2 infection pathogenesis is related to oxidative stress as a response to aggression. Med Hypotheses., 2020; 143: 110102: $1-5$.

11. Cessario J, Pierre-Louis V, Wahl J, Li Z, Empagliflozin, alone or in combination with liraglutide, limits cell death in vitro: role of oxidative stress and nitric oxide. Pharmacol Rep., 2021; 73(3): 858-867.

12. Chakraborty A, Chowdhury S, Bhattacharyya M, Effect of metformin on oxidative stress, nitrosative stress and inflammatory biomarkers in type 2 diabetes patients. Diabetes Res Clin Pract., 2011; 93(1): 56-62.

13. Choi T, Kim SS, Physiological Functions of Mitochondrial Reactive Oxygen Species. IntechOpen, 2019.

14. Connors JM, Levy JH, COVID-19 and its implications for thrombosis and anticoagulation. Blood, 2020; 135(23): 2033-2040

15. Coperchini F, Chiovato L, Croce L, Magri F, Rotondi M, The cytokine storm in COVID-19: An overview of the involvement of the chemokine/chemokine-receptor system. Cytokine Growth Factor Rev., 2020; 53: 25-32.

16. Dilek SO, Gurbuz F, Turan I, Celiloglu C, Yuksel $\mathrm{B}$, Changes in the presentation of newly diagnosed type 1 diabetes in children during the COVID-19 pandemic in a tertiary center in Southern Turkey. $J$ Pediatr Endocrinol Metab., 2021.

17. Dries SS, da Silveira Soares B, Ziulkoski AL, Verza SG, Linden R, de Andrade FM, Perassolo MS, Oxidative stress in patients with type 2 diabetes mellitus treated with metformin. Scientia Medica, 2017; 27(2): 25857:1-8

18. Duan J, Lu X, He G, On the penetration depth of reactive oxygen and nitrogen species generated by a plasma jet through real biological tissue. Physics of Plasmas, 2017; 24(7): 073506: 1-7.

19. Esteghamati A, Eskandari D, Mirmiranpour H, Noshad S, Mousavizadeh M, Hedayati M, Nakhjavani M, Effects of metformin on markers of oxidative stress and antioxidant reserve in patients with newly diagnosed type 2 diabetes: a randomized clinical trial. Clin Nutr., 2013; 32(2): 179-185.

20. Gandin A, Dizengremel P, Jolivet Y, Integrative role of plant mitochondria facing oxidative stress: The case of ozone. Plant Physiol Biochem., 2021; 159: 202-210.

21. Guan WJ, Liang WH, Zhao Y, Liang HR, Chen ZS, Li YM, Liu XQ, Chen RC, Tang CL, Wang T, Ou CQ, Li L, Chen PY, Sang L, Wang W, Li JF, Li CC, Ou LM, Cheng B, Xiong S, Ni ZY, Xiang J, Hu Y, Liu L, Shan H, Lei CL, Peng YX, Wei L, Liu Y, Hu YH, Peng P, Wang JM, Liu JY, Chen Z, Li G, Zheng ZJ, Qiu SQ, Luo J, Ye CJ, Zhu SY, Cheng LL, Ye F, Li SY, Zheng JP, Zhang NF, Zhong NS, He JX, China Medical Treatment Expert Group for C, Comorbidity and its impact on 1590 patients with COVID-19 in China: a nationwide analysis. Eur Respir J., 2020; 55(5): 2000547: 1-14.

22. Hamamoto S, Kanda Y, Shimoda M, Tatsumi F, Kohara K, Tawaramoto K, Hashiramoto M, Kaku $\mathrm{K}$, Vildagliptin preserves the mass and function of pancreatic beta cells via the developmental regulation and suppression of oxidative and endoplasmic reticulum stress in a mouse model of diabetes. Diabetes Obes Metab., 2013; 15(2): 153-63.

23. Heitzman J, Impact of COVID-19 pandemic on mental health. Psychiatr Pol., 2020; 54(2): 187-198.

24. Hossain MM, Tasnim S, Sultana A, Faizah F, Mazumder H, Zou L, McKyer ELJ, Ahmed HU, Ma P, Epidemiology of mental health problems in COVID19: a review. F1000Res., 2020; 9: 636: 1-16.

25. Hu B, Huang S, The cytokine storm and COVID-19. Journal of Medical Virology, 2021; 93(1): 250-256.

26. Iqbal A, Greig M, Arshad MF, Julian TH, Ee Tan S, Elliott J, Higher admission activated partial thromboplastin time, neutrophil-lymphocyte ratio, serum sodium, and anticoagulant use predict in-hospital COVID-19 mortality in people with Diabetes: Findings from Two University Hospitals in the U.K. Diabetes Res Clin Pract., 2021; 178: 108955: 1-12.

27. Ismail Hassan F, Didari $T$, Khan F, Niaz K, Mojtahedzadeh M, Abdollahi M, A Review on The Protective Effects of Metformin in Sepsis-Induced Organ Failure. Cell J., 2020; 21(4): 363-370.

28. Jain A, Jain A, Purohit S, COVID-19, Diabetes Mellitus, Corticosteroids: A Recipe for Disaster. Ear Nose Throat J., 2021; https://doi.org/10.1177/ 01455613211033687

29. Jiang L, Beals J, Whitesell NR, Roubideaux Y, Manson SM, Ai-SuperpfpTeam, Stress burden and diabetes in two American Indian reservation communities. Diabetes Care, 2008; 31(3): 427-429.

30. Jiang X, Wu D, Jiang Z, Ling W, Qian G, Protective Effect of Nicorandil on Cardiac Microvascular Injury: Role of Mitochondrial Integrity. Oxid Med Cell Longev., 2021; 2021: 4665632: 1-10.

31. Kang Q, Yang C, Oxidative stress and diabetic retinopathy: Molecular mechanisms, pathogenetic role 
FARMACIA, 2021, Vol. 69, 4

and therapeutic implications. Redox Biol., 2020; 37: 101799: 1-17.

32. Kelly SJ, Ismail M, Stress and type 2 diabetes: a review of how stress contributes to the development of type 2 diabetes. Annu Rev Public Health, 2015; 36: 441-462.

33. Khalid A, Rehman M, Ahmad A, Nitric oxide pathway as a potential therapeutic target in COVID-19. Farmacia, 2020; 68(6): 966-969.

34. Khanfar A, Al Qaroot B, Could glutathione depletion be the Trojan horse of COVID-19 mortality? Eur Rev Med Pharmacol Sci., 2020; 24(23): 12500-12509.

35. Klok FA, Kruip M, van der Meer NJM, Arbous MS, Gommers D, Kant KM, Kaptein FHJ, van Paassen J, Stals MAM, Huisman MV, Endeman H, Incidence of thrombotic complications in critically ill ICU patients with COVID-19. Thromb Res., 2020; 191: 145-147.

36. Komaravelli N, Casola A, Respiratory Viral Infections and Subversion of Cellular Antioxidant Defenses. $J$ Pharmacogenomics Pharmacoproteomics, 2014; 5(4): 1000141: 1-20.

37. Kountouri A, Korakas E, Ikonomidis I, Raptis A, Tentolouris N, Dimitriadis G, Lambadiari V, Type 1 Diabetes Mellitus in the SARS-CoV-2 Pandemic: Oxidative Stress as a Major Pathophysiological Mechanism Linked to Adverse Clinical Outcomes. Antioxidants, 2021; 10(5): 752: 1-20.

38. Kowluru A, Oxidative Stress in Cytokine-Induced Dysfunction of the Pancreatic Beta Cell: Known Knowns and Known Unknowns. Metabolites, 2020; 10(12): 480: 1-17.

39. Laforge M, Elbim C, Frere C, Hemadi M, Massaad C, Nuss P, Benoliel JJ, Becker C, Tissue damage from neutrophil-induced oxidative stress in COVID-19. Nat Rev Immunol., 2020; 20(9): 515-516.

40. Li C, Ford ES, Zhao G, Balluz LS, Berry JT, Mokdad $\mathrm{AH}$, Undertreatment of mental health problems in adults with diagnosed diabetes and serious psychological distress: the behavioral risk factor surveillance system, 2007. Diabetes Care, 2010; 33(5): 1061-1064.

41. Liu H, Wang L, Weng X, Chen H, Du Y, Diao C, Chen Z, Liu X, Inhibition of Brd4 alleviates renal ischemia/reperfusion injury-induced apoptosis and endoplasmic reticulum stress by blocking FoxO4mediated oxidative stress. Redox Biol., 2019; 24: 101195: 1-13.

42. Liviu I, Lixandru D, Gaman L, Ilie GM, Smeu B, Simona S, Petcu L, Picu A, Alina C, Ionescu-Tîrgovişte C, Guja C, Copaescu C, Stoian I, Oxidative stress profile and type 2 diabetes remission at 6 months after sleeve gastrectomy versus conservatory treatment. Farmacia, 2019; 67(1): 99-105.

43. Lobo V, Patil A, Phatak A, Chandra N, Free radicals, antioxidants and functional foods: Impact on human health. Pharmacogn Rev., 2010; 4(8): 118-126.

44. Lushchak VI, Free radicals, reactive oxygen species, oxidative stress and its classification. Chem Biol Interact., 2014; 224: 164-175.

45. Luyckx K, Seiffge-Krenke I, Hampson SE, Glycemic control, coping, and internalizing and externalizing symptoms in adolescents with type 1 diabetes: a crosslagged longitudinal approach. Diabetes Care, 2010; 33(7): 1424-1429.
46. Mantzarlis K, Tsolaki V, Zakynthinos E, Role of Oxidative Stress and Mitochondrial Dysfunction in Sepsis and Potential Therapies. Oxid Med Cell Longev., 2017; 2017: 5985209: 1-10.

47. Masharani U, German MS, Pancreatic Hormones and Diabetes Mellitus. Gardner DG, Shoback D. Greenspan's Basic \& Clinical Endocrinology 10th Edition. McGrawHill Medical: China, 2018: 87.

48. Mukhtar S, Mukhtar S, Letter to the Editor: Mental Health and Psychological Distress in People with Diabetes during COVID-19. Metabolism, 2020; 108: 154248.

49. Nicola P, Ardeleanu E, Gadau C, Dorobantu M, Darabont R, Tilea I, Varga A, Folescu R, Zamfir AS, Boanca M, Strat L, Baaj T, Gurgus D, Evaluation of Biochemical and Clinical Parametres of Hypertension with Type 2 Diabetes Mellitus. Rev Chim. (Bucharest), 2018; 69(9): 2402-2406.

50. Ntyonga-Pono MP, COVID-19 infection and oxidative stress: an under-explored approach for prevention and treatment?. Pan Afr Med J., 2020; 35(Suppl 2): 12: $1-2$.

51. Oguntibeju OO, Type 2 diabetes mellitus, oxidative stress and inflammation: examining the links. Int $J$ Physiol Pathophysiol Pharmacol., 2019; 11(3): 45-63.

52. Ogurtsova K, da Rocha Fernandes JD, Huang Y, Linnenkamp U, Guariguata L, Cho NH, Cavan D, Shaw JE, Makaroff LE, IDF Diabetes Atlas: Global estimates for the prevalence of diabetes for 2015 and 2040. Diabetes Res Clin Pract., 2017; 128: 40-50.

53. Qu SZhang C, Metformin Protects ARPE-19 Cells from Glyoxal-Induced Oxidative Stress. Oxidative Med Cell Longevity, 2020; 2020: 1740943: 1-12.

54. Ragab D, Salah Eldin H, Taeimah M, Khattab R, Salem R, The COVID-19 Cytokine Storm; What We Know So Far. Front Immunol., 2020; 11(1446): 1446: 1-4.

55. Ramos-Rincon JM, Perez-Belmonte LM, CarrascoSanchez FJ, Jansen-Chaparro S, De-Sousa-Baena M, Bueno-Fonseca J, Perez-Aguilar M, Arevalo-Canas C, Bacete Cebrian M, Mendez-Bailon M, Fiteni Mera I, Gonzalez Garcia A, Navarro Romero F, Tunon de Almeida C, Muniz Nicolas G, Gonzalez Noya A, Hernandez Milian A, Garcia Garcia GM, Alcala Pedrajas JN, Herrero Garcia V, Corral-Gudino L, Comas Casanova P, Meijide Miguez H, Casas-Rojo JM, Gomez-Huelgas R, Network SC, Cardiometabolic Therapy and Mortality in Very Old Patients With Diabetes Hospitalized due to COVID-19. J Gerontol A Biol Sci Med Sci., 2021; 76(8): e102-e109.

56. Rana W, Mukhtar S, Mukhtar S, Mental health of medical workers in Pakistan during the pandemic COVID-19 outbreak. Asian J Psychiatr., 2020; 51: 102080: 1-2.

57. Randeria SN, Thomson GJA, Nell TA, Roberts T, Pretorius E, Inflammatory cytokines in type 2 diabetes mellitus as facilitators of hypercoagulation and abnormal clot formation. Cardiovasc Diabetol., 2019; 18(1): 72: 1-15.

58. Ray PD, Huang BW, Tsuji Y, Reactive oxygen species (ROS) homeostasis and redox regulation in cellular signaling. Cell Signal., 2012; 24(5): 981-990. 
59. Ray PD, Huang BW, Tsuji Y, Reactive oxygen species (ROS) homeostasis and redox regulation in cellular signaling. Cell Signal., 2012; 24(5): 981-990.

60. Ren H, Shao Y, Wu C, Ma X, Lv C, Wang Q, Metformin alleviates oxidative stress and enhances autophagy in diabetic kidney disease via AMPK/ SIRT1-FoxO1 pathway. Mol Cell Endocrinol., 2020; 500: 110628: 1-13.

61. Rizzo MR, Barbieri M, Marfella R, Paolisso G, Reduction of oxidative stress and inflammation by blunting daily acute glucose fluctuations in patients with type 2 diabetes: role of dipeptidyl peptidase-IV inhibition. Diabetes Care, 2012; 35(10): 2076-2082.

62. Sagoo M, KGnudi L, Diabetic nephropathy: Is there a role for oxidative stress?. Free Radic Biol Med., 2018; 116: 50-63.

63. Saleh J, Peyssonnaux C, Singh KK, Edeas M, Mitochondria and microbiota dysfunction in COVID19 pathogenesis. Mitochondrion, 2020; 54: 1-7.

64. Sandireddy R, Yerra VG, Areti A, Komirishetty P, Kumar A, Neuroinflammation and oxidative stress in diabetic neuropathy: futuristic strategies based on these targets. Int J Endocrinol., 2014; 2014: 674987: $1-10$.

65. Scott KM, Von Korff M, Alonso J, Angermeyer MC, Bromet E, Fayyad J, de Girolamo G, Demyttenaere K, Gasquet I, Gureje O, Haro JM, He Y, Kessler RC, Levinson D, Medina Mora ME, Oakley Browne M, Ormel J, Posada-Villa J, Watanabe M, Williams D, Mental-physical co-morbidity and its relationship with disability: results from the World Mental Health Surveys. Psychol Med., 2009; 39(1): 33-43.

66. Seiglie JA, Serván-Mori E, Manne-Goehler J, Meigs JB, Jaime Miranda J, Sosa-Rubí SG, Silverman O, Wexler DJ, Wirtz VJ, Diabetes mellitus as a risk factor for SARS-CoV-2 test positivity in Mexico: A propensity score matched study. Diabetes Res Clin Prac., 2021; 171: 108953: 1-8.

67. Shi Q, Zhang X, Jiang F, Zhang X, Hu N, Bimu C, Feng J, Yan S, Guan Y, Xu D, He G, Chen C, Xiong X, Liu L, Li H, Tao J, Peng Z, Wang W, Clinical Characteristics and Risk Factors for Mortality of COVID-19 Patients With Diabetes in Wuhan, China: A Two-Center, Retrospective Study. Diabetes Care, 2020; 43(7): 1382-1391.

68. Sies H, Oxidative stress: a concept in redox biology and medicine. Redox Biol., 2015; 4: 180-183.

69. Sinha P, Matthay MA, Calfee CS, Is a "Cytokine Storm" Relevant to COVID-19? JAMA Intern Med., 2020; 180(9): 1152-1154.

70. Siragusa M, Oliveira Justo AF, Malacarne PF, Strano A, Buch A, Withers B, Peters KG, Fleming I, VEPTP inhibition elicits eNOS phosphorylation to blunt endothelial dysfunction and hypertension in diabetes. Cardiovasc Res., 2021; 117(6): 1546-1556.

71. Sivalingam S, Larsen EL, van Raalte DH, Muskiet MHA, Smits MM, Tonneijck L, Joles JA, von Scholten BJ, Zobel EH, Persson F, Henriksen T, Diaz LJ, Hansen TW, Poulsen HE, Rossing P, The effect of liraglutide and sitagliptin on oxidative stress in persons with type 2 diabetes. Sci Rep., 2021; 11(1): 10624: 1-8.

72. Soria-Castro E, Soto ME, Guarner-Lans V, Rojas G, Perezpeña-Diazconti M, Críales-Vera SA, Manzano
Pech L, Pérez-Torres I, The kidnapping of mitochondrial function associated with the SARS-CoV-2 infection. Histol Histopathol., 2021; 18354: 1-56.

73. Styskal J, Van Remmen H, Richardson A, Salmon $\mathrm{AB}$, Oxidative stress and diabetes: what can we learn about insulin resistance from antioxidant mutant mouse models?. Free Radic Biol Med., 2012; 52(1): 46-58.

74. Tilea I, Varga A, Serban RC, Past, Present, and Future of Blood Biomarkers for the Diagnosis of Acute Myocardial Infarction-Promises and Challenges. Diagnostics, 2021; 11(5): 881: 1-19.

75. Tilinca MC, Barabas-Hajdu EC, Tusa Ferencz G, Nemes-Nagy E, Involvement of inflammatory cytokines in obesity and its complications. Rev Romana Med Lab., 2018; 26(3): 359-372.

76. Tilinca MC, Pal S, Preg Z, Barabas Hajdu E, Tilinca R, Sallo MG, Nagy EN, The Relationship of Metabolic and Endocrine Parameters with Associated Diseases in Diabetes Mellitus. Rev Chim. (Bucharest), 2018; 69(5): 1288-1291.

77. Tilinca MC, Tiuca RA, Burlacu A, Varga A, A 2021 Update on the Use of Liraglutide in the Modern Treatment of "Diabesity": A Narrative Review. Medicina, 2021; 57(7): 669: 1-11.

78. Welsh P, Murray HM, Ford I, Trompet S, de Craen AJ, Jukema JW, Stott DJ, McInnes IB, Packard CJ, Westendorp RG, Sattar N, Group PS, Circulating interleukin-10 and risk of cardiovascular events: a prospective study in the elderly at risk. Arterioscler Thromb Vasc Biol., 2011; 31(10): 2338-2344.

79. WHO, Coronavirus disease (COVID-19) dashboard. Geneva: WHO, 2021, https://covid19.who.

80. Wu MY, Yiang GT, Lai TT, Li CJ, The Oxidative Stress and Mitochondrial Dysfunction during the Pathogenesis of Diabetic Retinopathy. Oxid Med Cell Longev., 2018; 2018: 3420187: 1-12.

81. Wysham C, Shubrook J, Beta-cell failure in type 2 diabetes: mechanisms, markers, and clinical implications. Postgrad Med., 2020; 132(8): 676-686.

82. Yaribeygi H, Sathyapalan T, Atkin SL, Sahebkar A, Molecular Mechanisms Linking Oxidative Stress and Diabetes Mellitus. Oxid Med Cell Longev., 2020; 2020: 8609213: 1-13.

83. Zeng J, Zhu L, Liu J, Zhu T, Xie Z, Metformin Protects against Oxidative Stress Injury Induced by Ischemia/ Reperfusion via Regulation of the IncRNA-H19/miR148a-3p/Rock2 Axis. Oxid Med Cell Longev., 2019; 2019: 8768327: 1-18.

84. Zhang P, Li T, Wu X, Nice EC, Huang C, Zhang Y, Oxidative stress and diabetes: antioxidative strategies. Front Med., 2020; 14(5): 583-600.

85. Zhang WQ, Tian Y, Chen XM, Wang LF, Chen CC, Qiu CM, Liraglutide ameliorates beta-cell function, alleviates oxidative stress and inhibits low grade inflammation in young patients with new-onset type 2 diabetes. Diabetol Metab Syndr., 2018; 10: 91: 1-8.

86. Zheng M, Wang X, Guo H, Fan Y, Song Z, Lu Z, Wang J, Zheng C, Dong L, Ma Y, Zhu Y, Fang H, Ye $S$, The Cytokine Profiles and Immune Response Are Increased in COVID-19 Patients with Type 2 Diabetes Mellitus. J Diabetes Res., 2021; 2021: 9526701: 1-8. 